УДК 376.091

DOI:

Наталя Шемигон, кандидат педагогічних наук, доиент кафедри педагогіки, методики та менеджменту освіти Української інженерно-педагогічної академї

\title{
ОРГАНІЗАЦІЯ АДАПТИВНОГО ІНКЛЮЗИВНОГО ПРОСТОРУ У ЗАКЛАДАХ ВИЩОЇ ОСВІТИ
}

У статті розглянуто питання організації адаптивного інклюзивного простору у закладах вищої освіти України, розкрито поняття “освітній простір”, “інклюзивний освітній простір”. Проаналізовано та визначено компоненти адаптивного інклюзивного простору, щуо забезпечують адаптацію студентів з особливими потребами до умов навчання у закладі вищуої освіти, та їх реалізацію у вітчизняній системі вищої иколи. Досліджено ефективність адаптивних можливостей інклюзивного освітнього простору, щзо перебуває в залежності від взаємодї та наповненості компонентів, щуо входять до його складу.

Ключові слова: інклюзивний освітній простір; компоненти; адаптивність; безбар'єрність; індивідуалізація; варіативність.

Лim. 8.

Nataliya Shemyhon, Ph.D.(Pedagogy), Associate Professor of the Pedagogy, Methodology and Management of Education Department Ukrainian Engineering and Pedagogical Academy

\section{ORGANIZATION OF ADAPTIVE INCLUSIVE SPACE IN HIGHER EDUCATION INSTITUTIONS}

The article identifies the problems on the way of implementation of inclusion in higher educational institutions of Ukraine: the development of issues, the design and organization of an inclusive educational space, which is directly related to the problem of adaptive possibilities of the educational space of a higher educational establishment; lack of definition of definition - inclusive educational space. The questions of organization of adaptive inclusive space in higher educational institutions of Ukraine are considered, the concept of "educational space", "inclusive educational space" is disclosed. It has been determined that inclusive processes in education broaden the understanding of the tasks and functions of the educational space, "inclusive educational space", in addition to the general features inherent in the educational space of any higher educational institution, has specific components - the components due to the inclusive component. Components of adaptive inclusive space, provide adaptation of students with special needs to studying conditions at higher educational institutions

In order to fulfill the adaptation function in relation to students with special educational needs, the inclusive educational space has to acquire the adaptive rice. Adaptability is seen as the ability of components of an inclusive educational space to be flexible, able to respond quickly and change in accordance with the needs of the educational sector and the participants in the educational process. It is the adaptability of the inclusive educational space that provides for the effective interaction of the individual with the educational space, the development of the professional and social qualities of a student with special needs. The efficiency of adaptive possibilities of the inclusive educational space, which depends on the interaction and filling of the components that are part of it, is investigated.

The analysis of the components showed their weak implementation in the inclusive educational space of higher education in Ukraine, which reduces, or makes practically impossible the implementation of the adaptive factor of the inclusive educational space. The article highlights the foregoing points of a need for further development of the conceptual foundations of adaptive inclusive space and the study of the implementation of its components. variability.

Keywords: an inclusive educational environment; components; an adaptation; barrier-free individualization;

П

остановка проблеми. Проблемі інклюзивного навчання у закладах вищої освіти України приділяються достатня увага в останні роки. Свропейський шлях розвитку, що обрала наша країна, передбачає високі освітні стандарти для всіх без виключення громадян України. Для країн Свропи включення - інклюзія людей з особливими потребами у соціум $є$ усталеною практикою, наша країна та освітня галузь перебуває тільки на початку цього шляху. Саме освіта, як галузь, що сприяе соціалізації, втіленню передових перетворень повинна стати флагманом, що забезпечить інклюзію людей з особливими потребами. У Законі України Про вищу освіту від 2014 р. ст.4п.1 задекларовано: “для реалізації права на вищу освіту особами 3 особливими освітніми потребами заклади вищої освіти створюють їм 
необхідні умови для здобуття якісної вищої освіти” [4]. Однак, існує низка проблем на шляху втілення інклюзї̈ у заклади вищої освіти України: спостерігаємо протиріччя між законодавчою базою, яка декларує реалізацію прав на необмежений доступ осіб з інвалідністю до всіх рівнів освіти та реальною практикою, що характеризується: наявністю бар'єрів, які перешкоджають доступу до вищої освіти; недостатньою розробленістю дидактичних та методичних засад інклюзії у вищій школі України, що сприятимуть швидшій адаптації молоді 3 особливими освітніми потребами до умов навчання у закладах вищої освіти; не розробленість питань, конструювання та організації інклюзивного освітнього простору, що безпосередньо пов'язано з проблемою адаптивних можливостей освітнього простору закладів вищої освіти; відсутність визначення дефініції інклюзивний освітній простір. Враховуючи вищевикладене, виникає необхідність дослідження питань організації адаптивного інклюзивного простору, уточнення поняття інклюзивний освітній простір, що, в свою чергу, дозволить забезпечити механізми адаптації до цього простору студентів 3 вадами здоров'я.

Аналіз останніх досліджень та публікацій. Сьогодні проблема реалізації інклюзивної освіти, стосовно завдань, доступності, організації активно досліджується як за кордоном, так і в нашій країні. Дослідженням вищеозначених питань займаються: Л.Байда,О.Безпалько,ГВ.Давиденко,М.С.Чайковський, А. Колупаєва. Забезпеченням умов інклюзивного навчання у закладах вищої освіти України займаються: К. Кольченко, Г. Нікуліна, П. Таланчук. Проте відсутні дослідження, присвячені проблемі адаптивних можливостей інклюзивного освітнього простору закладу вищої освіти та його компонентів.

Враховуючи актуальність проблеми, метою статті $\epsilon$ теоретична розробка питань організації інклюзивного освітнього простору у закладах вищої освіти, визначення його компонентів та адаптивних можливостей, що сприятиме вирішенню завдань соціалізації, професійної реалізації та саморозвитку студентів з особливими освітніми потребами.

Виклад основного матеріалу. Поняття “інклюзивний освітній простір” увійшло унауковий обіг починаючи з кінця XX століття. Завдяки інклюзії, як процесу, що почався в англомовних країнах у сфері освіти $80-x$ роках, розпочалися активні наукові пошуки у визначення поняття “інклюзивний освітній простір”.

Інклюзія - процес, що передбачає повне включення особистості з особливими потребами в освітній простір, змінює уявлення про функції та завдання освітнього простору. У науковій літературі існують різні визначення дефініції “інклюзивний освітній простір”. Перш ніж перейти до розгляду поняття інклюзивного освітнього простору, визначимо категорію “освітній простір”. Визначальна функція освітнього простору вищої школи, як феномену, це задоволення освітніх потреб особистості та гнучке реагування на зміну цих потреб. Відповідно, освітній простір розглядається як феномен, що забезпечує формування у майбутніх спеціалістів поліфункціонального професійного знання в єдності з практичним досвідом, утворює численні зв'язки у сфері педагогічної діяльності; сприяє усвідомлення суб'єктами різноманітних освітніх пропозицій і професійно значимого соціального досвіду, сформованого в освітньому оточенні [8].

Н. Касярум зазначає, що “освітній простір має певні характеристики: територіальна визначеність освітніх послуг, цілісність елементів освіти, системність, наявність просторових координат, інформаційність, особистісно-розвивальна спрямованість освіти, єдність вимог до змісту освіти на певному рівні та певній території, характерних для суспільства або громади при передачі соціального досвіду” [5, 64].

Освітній простір розглядається як динамічне середовище, яке змінюється разом з суб'єктом середовища (студентом), реагує на його потреби та потреби середовища. На думку Г. Григорова, освітній простір представляє собою систему, що розвивається та постає в динамічній єдності суб' єктів освітнього процесу та їх відносин. Між суб'єктами освітнього процесу існує структуроване різноманіття відносин, яке формує освітній простір, що складається у результаті освітньої діяльності $[1,113]$.

А. Цимбалару розглядає освітній простір як педагогічну реальність “у якій відбувається зустріч, взаємодія, осмислення і пізнання особистістю (подія) оточуючих іії елементів-носіїв культури (освітнього середовища), що забезпечує суб' єктивацію і прогресивний розвиток об'єктів (фігурантів і предметів). Освітній простір як система педагогічних факторів та умов освоєння особистістю у процесі становлення спеціально організованого педагогічного середовища може бути об'єктом цілеспрямованого педагогічного впливу, формування" [7, 45]. Науковцями відмічається, що освітній простір є частиною соціального простору, у межах якого він, власне, й існує, i, відповідно, освітній простір перебуває у діалектичній взаємодії з соціальним простором. 
Отже, підсумовуючи існуючі наукові погляди, освітній простір представляє собою систему, що має свою структуру в межах якої відбувається розвиток професійних та особистісних якостей студента, систему, що перебуває у динамічній взаємодії з суб'єктами освітнього середовища та соціальним простором (гнучко реагує на запити суспільства та учасників освітнього процесу), піддається організаційним та проектувальним впливам тобто управлінню.

Як зазначалося вище, інклюзивні процеси у освіті, певним чином, розширюють розуміння завдань та функцій освітнього простору. Зараз, у науковій думці активно обговорюються визначення поняття “інклюзивний освітній простір”, крім загальних ознак, що виокремлені вище та притаманні освітньому простору будьякого закладу вищої освіти, виокремлюються специфічні складові частини - компоненти, обумовлені інклюзивною складовою. Виокремлюються наступні компоненти інклюзивного освітнього простору:

- корекційний компонент;

- безбар'єрність, як компонент інклюзивного освітнього простору;

- доступність освітніх ресурсів;

- індивідуалізація та варіативність інклюзивного освітнього простору [8, 79].

Вказані компоненти мають забезпечити адаптацію до умов навчання у вищому навчальному закладі. Адаптація виступає основою інклюзії та, як специфічний складовий елемент, забезпечує пристосування студента 3 особливими освітніми потребами до умов інклюзивного освітнього простору, інтеграцію у студентські групи, (як особливі соціальні утворення), забезпечує активну діяльність по засвоєнню нового життєвого досвіду, прийняття норм та цінностей нового для себе середовища закладу вищої освіти.

Розрізняють три ступеня адаптованості особистості. Адаптованість може бути внутрішньою, коли під впливом зовнішнього середовища повністю змінюються функціональні структури і системи особистості; зовнішня поведінкове пристосування особистості до вимог середовища без перебудови внутрішніх структур особистості; змішана, при якій особистість частково перебудовується і підлаштовується до середовища, його цінностей, норм, i, водночас зберігає своє Я, свою самостійність [3, 7]. Слід зазначити, що розглядаючи освітню галузь треба зауважити, що адаптація має обопільний процес перебудови та змін, як зовнішнього середовища, у даному випадку інклюзивного освітнього простору з одного боку, так і учасників освітнього процесу 3 іншого. Іншими словами, щоб виконувати функцію адаптації по відношенню до студентів 3 особливими освітніми потребами, інклюзивний освітній простір має набути рис адаптивного. Адаптивність розглядається, як здатність компонентів інклюзивного освітнього простору до гнучкості, можливості швидко реагувати та змінюватися у відповідності до потреб освітньої галузі та учасників освітнього процесу. Саме адаптивність інклюзивного освітнього простору забезпечує ефективну взаємодію особистості з освітнім простором, розвиток професійних та соціальних якостей студента 3 особливими потребами.

Ефективність адаптивних можливостей інклюзивного освітнього простору залежить від взаємодії та наповненості компонентів, що входять до його складу. Аналізуючи перший - корекційний компонент, слід відмітити що він базується на забезпеченні особливостей викладання професійних дисциплін в залежності від нозології студента. В останні роки в Україні відмічаються значні зрушення в напрямку втілення інклюзивної освіти, але вони передусім стосуються загальної середньої освіти. Згідно статистичних даних, розміщених на сайті МОН, збільшуються кількість учнів з особливими потребами у загальноосвітніх навчальних закладах, створюються ресурсні центри, що забезпечують надання інклюзивної освіти. Але у галузі вищої освіти ситуація набагато складніша. Через брак державної підтримки в українських 3 ВО зменшусться кількість студентів 3 інвалідністю. У освітній роботі зменшується частина корекційної складової, оскільки, кількість працівників дефектологів значно менша, ніж у спеціалізованих закладах; викладачі, що читають спеціальні та загальноосвітні дисципліни не володіють всіма необхідними методами та техніками дефектології [8]. Крім того, у більшості навчальних закладів I - IV рівнів акредитації відсутні ресурсні центри з технічними засобами навчання, що допомагають переводити навчальний матеріал у зручний для сприйняття студента формат, це не дає змоги компенсувати сенсорні порушення, які заважають таким студентам сприймати у повному обсязі навчальний матеріал. Зазначається, що поза увагою залишається питання широкого впровадження української жестової мови як у сферу вищої освіти, так і обслуговування та діяльність органів влади усіх рівнів. Відсутні нормативи роботи викладачів, перекладачів жестової мови, кураторів та інших фахівців, які 
працюють в інклюзивному освітньому середовищі навчальних закладів I - IV рівнів акредитації [6]. Відповідно, відсутнє гнучке реагування на потреби студента, що на практиці призводить до посилення обмежень у навчанні, оскільки студент потрапляє не тільки у новий незнайомий освітній простір, але й у простір, який не відповідає каналам сприйняття інформації таких студентів. Забезпечення корекційного компонента інклюзивного освітнього простору вимагає запровадження посад асистентів дефектологів, розвиток інклюзивних ресурсних центрів у закладах вищої освіти.

Такий компонент, як безбар'єрність слід розділити на архітектурну та соціальну складову. Заклади вищої освіти України мають не адаптовані для потреб таких студентів

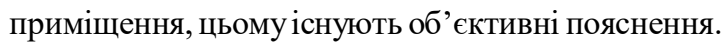
По-перше, це брак фінансування, а по-друге, деякі ЗВО знаходяться в історичних спорудах, переобладнання яких неможливе, оскільки ці будівлі є пам'ятками архітектури. До соціальних бар'єрів ми відносимо проблеми комунікативної взаємодії здорових студентів зі студентами, що мають вади здоров'я. Як свідчать дослідження, здорові студенти вказували на те, що побоюються студентів 3 вадами, не знають, як доречно запропонувати їм допомогу, чи правильно зрозуміють їх і тому намагаються, по можливості, уникнути спілкування, якщо не бачать позитивної зворотної реакції. Присутні і внутрішні бар'єри у студентів $з$ вадами здоров'я: неготовність до навчання, відсутність належного рівня знань, неготовність самих студентів 3 особливими потребами до спілкування: вони зазначали, що їм важко ініціювати спілкування, не маючи достатнього такого досвіду. До того ж, вони висловлювали побоювання, що можливо їх одногрупники будуть насміхатися над їх безпорадністю або зовнішнім виглядом, тому не виступають ініціаторами таких контактів. Здорові студенти також не наважуються виступати ініціаторами таких контактів, оскільки не знають, як правильно запропонувати свою допомогу, не мають досвіду спілкування з однолітками, що мають особливі потреби [6]. Така проблема $є$ характерною не тільки для вітчизняної вищої освіти, але і для інклюзивної освіти у Свропі. Згідно з соціологічними дослідженнями, проведеними в Європі, виявилося, що певні комунікативні бар'єри мають місце. Так, найтісніші контакти виникають між здоровою молоддю та студентами, що мають захворювання опорно-рухового апарату $(12,4 \%)$, потім відхилення розумового розвитку $(12,9 \%)$. Меншою мірою вади слуху, мови, зору $(9,1 \%)$.
Спостерігається також ідентичне ставлення викладачів по відношенню до студентів $з$ вадами. Специфічне ставлення до молоді з особливими потребами $з$ боку педагогів значною мірою впливає на успішну реалізацію інклюзивної освіти, оскільки саме в навчальному середовищі молодь із вадами розвитку реалізує особисте й соціальне “я”. [2]. 3 одного боку, викладачі не мають досвіду спілкування зі студентами, що мають особливі потреби, з іншого, викладачі не мають дидактичних знань щодо особливостей викладання таким студентам, оскільки методика викладання перебуває в залежності від функціонального порушення студента. Крім того, не слід забувати, що спілкування студентів 3 вадами не обмежується викладачами та одногрупниками. Студентське життя передбачає спілкування $з$ адміністрацією, бібліотекарями, студентськими службами, технічним персоналом, що при наявності комунікативних бар'єрів $з$ обох сторін стає фактично неможливим. За таких обставин адаптивні можливості інклюзивного освітнього простору не реалізуються. Подібна ситуація $\epsilon$ типовою для всього українського суспільства. Причини такого ставлення полягають у стереотипному сприйнятті неповноправних людей, що зумовлює відсторонення з боку викладачів та однолітків.

Компонент - доступність освітніх ресурсів прямо пов'язаний 3 корекційною складовою. Доступність освітніх ресурсів, передусім, передбачає забезпечення участі у навчанні та зменшення, а в ідеалі, ліквідації обмежень у навчанні, що є важливим показником адаптивності інклюзивного освітнього простору. Основний ресурс для втілення вказаного компоненту - це наявність у навчальних закладах індивідуального технічного забезпечення для навчання студентів, які, в залежності від вад здоров'я, допомагають переводити навчальний матеріал у зручний для сприйняття студента формат. Необхідні ресурси мають поодинокі навчальні заклади, що звісно, не може змінити картину в цілому, ресурсний центр існує у “Львівській політехніці", міжнародному університеті "Україна".

Як зазначалося вище, всі компоненти адаптивного освітнього простору взаємозалежні та підсилюють дію один одного. Недостатню реалізацію такого компоненту як доступність освітніх ресурсів можна, певним чином, мінімізувати за рахунок компоненту індивідуалізації та варіативності навчання. Інвалідність студента призводить до складності у сприйнятті інформації та аналізі явищ. Компонент індивідуалізації та варіативності 


\section{ОРГАНІЗАЦІЯ АДАПТИВНОГО ІНКЛЮЗИВНОГО ПРОСТОРУ У ЗАКЛАДАХ ВИЩОЇ ОСВІТИ}

передбачає здатність інклюзивного освітнього простору до постійного самовдосконалення, що передбачає вирішення педагогічних завдань та ситуацій, які викликані труднощами таких студентів та застосування нестандартних підходів для їх вирішення, які не заплановані навчальним планом; такі рішення приймаються ситуативно, у перебігу навчального процесу. Навчальний план передбачає активізацію максимуму каналів інформації, які здатний сприймати студент 3 обмеженнями. Важливим елементом індивідуалізації та варіативності $є$ реагування на потреби окремо взятого студента через організацію інтерактивної взаємодії викладач-студент, формування чинників, що посилюють сприйняття інформації. Розвиток вміння знаходити не тільки потрібні знання з різних джерел, а, також, створення для кожного студента індивідуальної траєкторії навчання з урахуванням особливих потреб. За таких умов багато залежить від майстерності самого викладача, який виступає у ролі своєрідного координатора, що допомагає сформувати студенту свій план навчальних дій, свою стратегію майбутнього професійного розвитку, допомагає визначити реальну мету навчання на основі реальних можливостей, співвіднести їх з вимогами навчального простору, що, в свою чергу, включає максимальні і адаптивні можливості освітнього простору з включення такого студента у навчання.

Висновки. Таким чином, інклюзивний освітній простір є адаптивною системою, що перебуває у динамічній взаємодії з суб'єктами освітнього середовища та соціальним простором, складається 3 компонентів, що забезпечують здатність гнучко реагувати та змінюватися у відповідності до освітніх потреб студента 3 інвалідністю, забезпечуючи таким чином можливості особистісного та професійного розвитку. Аналіз компонентів показав їх слабку реалізацію в інклюзивному освітньому просторі вищої школи України, що зменшуе, або робить практично неможливою реалізацію адаптивного чинника інклюзивного освітнього простору. Вищевикладене свідчить про необхідність подальшої розробки концептуальних засад адаптивного інклюзивного простору та вивчення реалізації його компонентів.

\section{ЛІТЕРАТУРА}

1. Григоров Г.А. Методологічні підходи до дослідження освітнього простору. Грані. №9(101). 2013. C.101-113.

2. Давиденко Г.В. Інклюзія у вищих навчальних закладах Європейського Союзу. Вінниця, 2015.314 с.

3. Енциклопедія для фахівців соціальної сфери / за заг.ред.проф. І.Д.Звєрєвої. Київ,Сімферополь, 2012. 536 с.
4. Закон України Про вищу освіту від 01.07.2014№1556-VII. URL: https:zakon.gov.ua/go 1556$18 /$

5. Касярум Н. Освітній простір : становлення поняття. Витоки педагогічної майстерності. Вип.12. 2013. C.107-113.

6. Потапюк Л.М. Особливості реабілітації осіб 3 вадами зору. Науковий часопис НПУ імені М.Драгоманова. Серія 19. (Корекиійна педагогіка). Вип.12.2008. С.60-69.

7. Цимбалару А.Д. Освітній простір: сутність, структура, механізми створення. Український педагогічний журнал. Київ,№1 2016. С.41-50.

8. Чайковський М.Є. Інклюзивний освітній простір як середовище соціально-педагогічної роботи 3 молоддю $з$ інвалідністю. 3б. наукових праць Хмельницького інституту соціальних технологій Університету “Украӥна”.№19. Хмельницький, 2017. C. $76-80$.

\section{REFERENCES}

1. Grygorov, G.A. (2013). Metodologichni pidxody do doslidzhennya osvitnogo prostoru [Methodological approaches to the study of educational space]. Grani, no.9(101), pp. 101-113. [in Ukrainian].

2. Davydenko, H.V. (2015). Inkliuziia u vyshchykh navchalnykh zakladakh Yevropeiskoho Soiuzu [Inkluziyuyu at higher educational institutions of the European Union]. Vinnytsia, p.314. [in Ukrainian].

3. Entsyklopediia dlia fakhivtsiv sotsialnoi sfery (2012). [Encyclopedia for professionals in the social sphere]. (Ed.).I.D.Zvierieva, Kyiv,Simferopol. [in Ukrainian].

4. Zakon Ukrainy Pro vyshchu osvitu vid 01.07.2014№1556-VII [Law of Ukraine on Higher Education 01.07.2014№1556-VII]. [in Ukrainian].

5. Kasiarum, N. (2013). Osvitnii prostir : stanovlennia poniattia [Educational space: the formation of the concept]. The origins of pedagogical skill. vol.12. pp.107113. [in Ukrainian].

6. Potapiuk, L.M. (2008). Osoblyvosti reabilitatsii osib $\mathrm{z}$ vadamy zoru [Features of rehabilitation of visually impaired people]. Scientific journal NPU named after Mykhaylo Drahomanov. Series 19. (Correctional Pedagogy). Vol. 19. pp. 60-69. [in Ukrainian].

7. Tsymbalaru, A.D. (2016). Osvitnii prostir: sutnist, struktura, mekhanizmy stvorennia [Educational space: essence, structure, mechanisms of creation]. Ukrainian Pedagogical Journal. No. 1, pp.41-50. [in Ukrainian].

8. Chaikovskyi, M.Ye. (2017). Inkliuzyvnyi osvitnii prostir yak seredovyshche sotsialno-pedahohichnoi roboty $\mathrm{z}$ moloddiu $\mathrm{z}$ invalidnistiu [Inclusive educational space as a medium of social and pedagogical work with youth with disabilities]. A collection of scientific works of the Khmelnytskiy Institute of Social Technologies of the University of Ukraine. No.19. Khmelnytskyi, pp.7680. [in Ukrainian].

Стаття надійшла до редакції 05.06.2019 